\title{
Irrigation application efficiency and uniformity of water distribution using multi-outlet pipe and resource conservation technologies
}

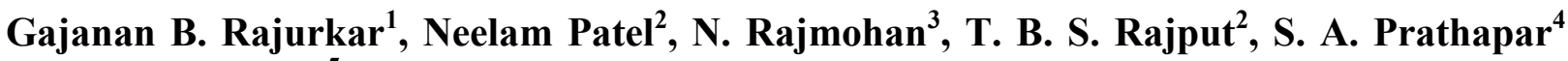 \\ and Cini Varghese ${ }^{5}$ \\ ${ }^{1}$ Division of Agricultural Engineering, Indian Agricultural Research Institute, New Delhi-110012, INDIA \\ ${ }^{2}$ Water technology center, Indian Agricultural Research Institute, New Delhi-110012, INDIA \\ ${ }^{3}$ International Water Management Institute, NASC Complex, DPS Marg, New Delhi, 110012, INDIA \\ ${ }^{4}$ Groundwater Modelling Unit, NSW Office of Water, Level 10 Macquarie Tower, 10 Valentine10 Av, PO Box \\ 3720, Parramatta NSW 2150, AUSTRALIA \\ ${ }^{5}$ Division of Agricultural Statistics, Indian Agricultural Statistics Research Institute, New Delhi-110012, INDIA \\ *Corresponding author. E-mail: rajurkargb@gmail.com
}

Received: February 4, 2016, Revised received: July 7, 2016; Accepted: October 23, 2016

\begin{abstract}
Irrigation experiments were conducted during November to April under wheat crop in the winter season of 2012-13 and 2013-14 in the farmer's field at Galibkhedi village located in Karnal District, Haryana State, India. In the study, collapsible multi-outlet pipe (MOP) along with single outlets pipe (SOP) was tested in farmer's field under wheat cultivation. Irrigation was carried out in five treatments including tillage $(T)$ with SOP and MOP; zero-tillage (ZT) with SOP and MOP, and furrow irrigation with raised bed (FIRB). Iso-time profile of waterfront spreading and advance indicated that irrigation water distribution was uniform under the plot irrigated using MOP as compared to plot irrigated using SOP. In addition, water distribution was uniform under zero tilled plots as compared to tilled plot. Results implied that MOP has several advantages over SOP in terms of application efficiency (AE) and uniformity of water distribution. Average application efficiency for the first study year was found to be in the order of ZT-MOP $(82.41 \%)>\operatorname{FIRB}(76.79 \%)>$ ZT-SOP $(75.25 \%)>$ T-MOP $(74.85 \%)>$ T-SOP $(69.79 \%)$. Average application efficiency for the second study year was found to be in the same order as first year with some deviation in values. In the second year values of mean application efficiencies were ZT-MOP $(82.58 \%)>$ FIRB $(77.13 \%)>$ ZT-SOP $(73.04 \%)>$ T-MOP $(69.65 \%)>$ T-SOP $(66.13 \%)$. Overall, this study concludes that irrigation under wheat crop using collapsible multi-outlet pipe (MOP) with zero tillage practices is a suitable option for surface irrigation that accomplishes uniform distribution of water with higher application efficiency.
\end{abstract}

Keywords: Application efficiency, Multi-outlets pipe, Water advance front, Zero-tillage

\section{INTRODUCTION}

In India, surface irrigation is the oldest and most common method of irrigation for wheat crop. The majority of wheat growers in the Indo-Gangetic Plains (IGP) of India practices surface irrigation either through flooding or check basin methods (Jat et al., 2011). Wheat being a densely planted crop, limits the use of microirrigation by the producers due to economic concerns. Hence, surface irrigation remains a popular irrigation system for wheat crop in the IGP. Current practices of surface irrigation in IGP results in the movement of water in two-dimension from the head to tail end of the field. Invariably, this results in non-uniform distribution of water, and excessive percolation losses near the outlet due to more infiltration opportunity time. This approach results in some areas remaining under watered or over-watered. Thus, non-uniform distribution of water leads to spatial variability in crop growth and grain production owing to non uniform availability of water and nutrients in the effective root zone of crop (Li et al., 2016). Therefore, irrigation systems need to be designed to apply water in the most efficient way possible to prevent unnecessary losses and water wastage (Burt et al., 1997). Optimum crop growth and yield can be obtained under an irrigation system with high uniformity of water application in which each plant will get an equal opportunity to access the applied water and nutrients (Clemmens and Solomon, 1997). The factors influencing the hydraulic processes like water infiltration and uniformity of water distribution need to be considered to improve efficiency of irrigation methods (Hlavek, 1992). The uniformity of water distribution can be achieved to a greater extent using sprinkler and drip irrigation systems (Varlev, 1976; Stern and Bresler, 1983; Seginer, 1983; Moteos et al., 1997; Li and Rao, 2000; Dechmi et al., 2003; Zhang et al., 2013; El-wahed et al., 2015). However, initial cost required to install micro-irrigation systems restrict its use for closely spaced crops viz. wheat. A ISSN : 0974-9411 (Print), 2231-5209 (Online) All Rights Reserved (C) Applied and Natural Science Foundation www.jans.ansfoundation.org 
much smaller investment is generally required in case of surface irrigation system compared to sprinkler and drip irrigation, if extensive land levelling is not needed.

An alternative method to distribute water uniformly and efficiently is to introduce collapsible (MOP) multioutlet pipe instead of conventional practice of applying irrigation through single outlet pipe (SOP). Technique of water application through collapsible multi-outlet pipe (MOP) is similar to technique of applying water to field by using gated pipe. The difference between Gated pipe and collapsible multi-outlet pipe is that in gated pipe, the flow rate out of each gate is controlled by the percent opening of the gate whereas in MOP, instead of gates, the permanent minor outlets of designed diameter are punched at specific interval on a side of collapsible canvas pipe to discharge predetermined amount of water. In this study, MOP was employed instead of gated pipes in the farmer's wheat field. MOP can be used during irrigation and then it could be disconnected from the source, rolled and stored in safer place. Thus, it will not disturb the farmers activities like land preparation as well as intercultural operations. MOP collapsible canvas pipe installs faster than gated pipe and can be purchased in larger diameters. The larger diameter pipe will deliver more water per unit time to the field and can facilitate in improving irrigation application efficiency of the farmers. In addition, punching outlets on side of collapsible canvas pipe is easier than installing gates or ports on gated pipe. Earlier studies employed gated pipes for irrigation in various countries like Australia, China, Egypt and Iran and reported that water consumption rate reduced from 28 to 25 percent and increase in water use efficiency by about 30 percent, compared to traditional methods (Karami and Samadi, 2005). Gated pipe system for surface irrigation over conventional surface irrigation system has several advantages, including water saving, increase in water use efficiency and increase in crop yield (Jibin and Foroud, 2000; Tantawy et al., 2000; Rady, 1993). Osman (2002) reported that water productivity could be increased with significant rise in wheat grain production using gated pipe irrigation technique. Under favourable conditions, the irrigation efficiency of over $80 \%$ can be attained by using the corrugated portable gated pipes (Zimmerman, 1966). The maximum distribution uniformity by using perforated pipe system can be achieved with small uphill slope (Hassan, 1998). Fischbach and Somerhalder (1971) reported 91.9\% water application efficiency using an automatic surface irrigation system with gated pipes. Osman (2000) pointed out that precision landlevelling with proper designing of gated pipes irrigation system, may significantly improve water distribution uniformity under wheat crop.

The resource conservation technologies (RCTs) which include zero-tillage planting, raised-bed planting, laser land levelling etc. are currently emerging as vital prof- itable technologies in the IGP. Several researchers have reported definitive advantages of RCTs in terms of rise in grain production, water saving, increase in water productivity and profitability, allowing early or timely sowing of wheat, improving soil properties, etc. (Anonymous, 2003; De-Vita et al., 2007; Bhushan et al., 2007; Jat et al., 2009; Montazar et al., 2008; Jat et al., 2011; Sharma et al., 2011). Subsequently, farmers in the IGP are accelerating the adoption of RCTs as these are profitable and add value to system as a whole. On farm irrigation management with resource conservation technologies would help to improve irrigation efficiency. Common measure of irrigation efficiency is application efficiency, which signifies how much of the water applied is actually used for the crop growth. A specific objective of this study was to evaluate application efficiency and uniformity of water distribution using collapsible multi-outlet pipe (MOP) under conventional and zero tillage practices in wheat crop, in farmers field of IGP, India.

\section{MATERIALS AND METHODS}

Study area description: Irrigation experiments were conducted during November to April under wheat crop in 2012-13 and 2013-14 at the Farmer's field at Galibkhedi village located in Karnal District, Haryana, India $\left(29^{\circ} 48^{\prime} \mathrm{N}\right.$ latitude, $76^{\circ} 53^{\prime} \mathrm{E}$ longitude). The region of Karnal falls under tropical climate and experiences summer, winter and monsoon seasons. The average annual rainfall of this region is $675 \mathrm{~mm}$, which is received mainly during July to September. Soil core samplings were carried out in the experimental site before the commencement of irrigation up to the depth of $100 \mathrm{~cm}$, and the samples were analysed for its physico-chemical properties (Bouyoucos, 1927; Jackson, 1973). Soil of the study site was clay loam upto $60 \mathrm{~cm}$ and silty clay loam from $60 \mathrm{~cm}$ to $100 \mathrm{~cm}$. The depth wise percentages of sand, silt and clay minerals, bulk density, $\mathrm{pH}$ and EC of soils are given in Table 1. Groundwater level at this site normally fluctuates between 20 and $25 \mathrm{mbgl}$. Thus, the groundwater level precludes any upward capillary movement of water into the root zone.

Treatment details: The experiments were carried out in five plots with different on-farm water management practices. The management practices adopted in this study are given below:

Conventional tillage with Surface irrigation through single outlet pipe (T-SOP).

Zero tillage with Surface irrigation through single outlet pipe (ZT-SOP).

Conventional tillage with Surface irrigation through multi-outlet pipe (T-MOP).

Zero tillage - Surface irrigation through multi-outlets pipe (ZT-MOP).

Furrow irrigation with raised bed (FIRB).

The conventional tillage with surface irrigation using 
single outlet pipe having corner or Fan inflow geometry is a common management practice in the IGP of India; Under the resource conservation technologies, Zero tillage practices and raise-bed planting were implemented under precise leveled field obtained using laser land leveller. The linear inflow geometry was obtained under surface irrigated basin using multioutlets pipe and also under FIRB (Fig. 1).

Design of experimental plot: The experiments were conducted in the field having area of $6750 \mathrm{~m}^{2}$. The field was divided into five experimental plots. Four plots were of the size $30 \times 50 \mathrm{~m}$ each and another plot for FIRB treatment was with $15 \times 50 \mathrm{~m}$ size (Fig. 2). Experiments were conducted in the same fie-ld during 2012-13 and 2013-14. The field was laser leveled for precise application of irrigation water using tractor operated laser land leveler. The wheat cultivars HD2851 were sown in the field in the month of November 2012 and November 2013 using $100 \mathrm{~kg}$ seed $\mathrm{ha}^{-1}$ for flat bed and $75 \mathrm{~kg}$ seed $\mathrm{ha}^{-1}$ for raised beds. Flat bed planting was carried out using Zero till seed-cum-fert drill at a row-to-row spacing of $22.5 \mathrm{~cm}$. For raisedbed seeding, raised bed planter was used. Irrigations were applied as per the crop water requirement based on soil moisture condition of the field. Total three irrigations were applied during the year 2012-13 and two irrigations were applied in the year 2013-14. Remaining crop water requirement was fulfilled using the moisture obtained by rainfall occurred during the cropgrowing period. In the first irrigation event, water was applied even after the water reached at the tail end of the field to attain the required depth of irrigation. Thus, the total amount of water applied in each plot was kept same in first irrigation event.

General features of irrigation system: PVC pipes of $140 \mathrm{~mm}$ diameter were laid on the land surface to carry water from source to field for irrigation. Irrigation system consisted of five butterfly valves (5") to control the flow of water in different experimental plots. A water meter was installed to measure the cumulative volume of water during irrigation events. In case of surface irrigation through a single outlet pipe (SOP), the outlet was fixed at the middle of the plot at its head end. In surface irrigation through multiple outlets pipe (MOP), numbers of minor outlets were punched at an interval of $0.75 \mathrm{~m}$ on single side along the entire length of the pipe, equal to width of the plot. MOP was placed along the width wise on upper head of the field. The lengths of collapsible pipe used on either sides of the butterfly valve were $15 \mathrm{~m}$ each (Fig. 2).

The collapsible (Canvas) pipe was used for MOP because it has several advantages over PVC pipes, such as being easy to roll, less weight, easily removable from main line, easy to carry from one field to another etc (Fig. 3). In addition, $60 \mathrm{~m}$ long collapsible canvas pipes are available at affordable prices in the market. Sixty-meter long, collapsible canvas pipe was divided into four parts as per the experimental plot requirement. The diameter of minor outlet was determined using standard orifice formula, considering major and minor head losses calculated through Hazen-William Formula (Williams and Hazen, 1920).

Installations of field instruments for data collection: A six access tubes (1 m long) were installed in each plot up to the depth of $60 \mathrm{~cm}$. Therefore, total thirty access tubes were installed in the experimental plot as per the designed location and at desired spacing using standard installation tools (Fig. 4). Slurry of soil and water was poured around the access tube to fill the air gap and to fit the access tube firmly in the soil. These access tubes were used to guide the probe of Frequency Domain Reflectometry (FDR) sensor to measure the soil water content in root zone of wheat crop. Apart from regular measurement, soil water content was also measured, before and after each irrigation events. To obtain the detailed dataset of water front advance during irrigation events, field stakes (plastics) were installed at $5 \times 5 \mathrm{~m}$ grid in all the experimental plots (Fig. 4). Water front advance with time was recorded and the resulting data was used to plot the iso-time profiles of water spreading and advance using tool SURFER (v.8.0). The obtained iso-time contours were used to examine the uniformity of water application under different water application and tillage practices.

FDR Sensor and its calibration: FDR sensor (Sentek) uses the dielectric property of water but in different way than Time Domain Reflectometry, TDR (Bilskie, 1997). Probe usually consists of two or more electrodes (i.e., plates, rods, or metal rings around a cylinder) that are inserted into the soil. On the ring configuration, the probe is introduced into access tube installed in the field. Thus, when an electrical field is applied, the soil around the electrodes (or around the tube) forms the dielectric of the capacitor that completes the oscillating circuit. The use of an access tube allows multiple sensors to take measurements at different depths. It provides the measurement of soil water contents from 0 to $150 \mathrm{~cm}$ of depth of soil at an interval of 5, 10, $15 \mathrm{~cm}$ etc. Calibration of the FDR Sensors was made by comparing Scaled Frequency readings from an access tube installed in the field with values of volumetric water content determined gravimetrically from immediately adjacent to the tube. When these values were plotted on a graph, they form a relationship that was described by a mathematical equation. In this way the moisture levels sent from the sensor are directly related to real values determined in the soil. As well as calibrating the soil, each sensor has been normalized in water and air to establish the water and air counts for the scaled frequency calculation.

Application efficiency: The performance of surface irrigation system can be evaluated based on the thorough observations of soil water contents before and after each irrigation events. Here the performance of 
irrigation system was evaluated based on application efficiencies. Application efficiency provides a general indication of irrigation system performance of delivering water from conveyance system to the effective root zone of crop. The main objective of determining the application efficiency is to know the volume of water to apply and store in the root zone of crop to meet the crop water requirement. It mainly depends on on-farm management practices, characteristics of soils, slope of the field, stream size and method of water application. It is essentially a quotient obtained by dividing actual volume of stored water in the root zone by the volume of water applied to the field and can be expressed mathematically as:

Application Efficiency, $\mathrm{E}_{\mathrm{a}}(\%)=\left(\mathrm{V}_{\mathrm{S}} / \mathrm{V}_{\mathrm{a})} * 100\right.$

Where, $V_{s}$ is volume of water stored in the root zone of crop and $\mathrm{V}_{\mathrm{a}}$ is Volume of water applied to the plot

Volume of water stored in root zone of crop was determined by taking the product of difference between soil water content before and after irrigation event and the area of plot. The total amount of water applied to individual plot was recorded by water meter (Kanti).

Statistical analysis: To test the differences between treatment means, the data on application efficiencies of entire irrigation events for the year 2012-13 and 201314 were analyzed with SPSS (v. 16.0) for one-way ANOVA. Duncan's multiple range test (DMRT) was used at the $\mathrm{P}<0.05$ level of probability to obtain the homogenous sets.

\section{RESULTS AND DISCUSSION}

The irrigation experiments were carried out in 2012-13 and 2013-14 under wheat crop to evaluate the performance of water application techniques under tillage and zero-tillage plot. The data sets of volumetric water contents, before and after irrigation events, and amount of water applied were recorded in each irrigation events. The water advance and spreading time required to evaluate the performance of the irrigation systems were recorded only at first irrigation event. First irrigation was applied at the crown root initiation (CRI) stage of wheat crop, which generally appears 21-25 days after sowing. It was difficult to record the water advance timing during other irrigation events as height of crop was increased due to which water advance front was not visible. Therefore, the datasets of only two irrigation events that were recorded at CRI stage of crop in the month of Decemeber-2012 and December-2013 were used to plot iso-time profiles of water spread and its advance. Application efficiency was determined for the entire irrigation events applied in the study year 2012-13 and 2013-14.

Iso-time profiles of water spread and its advance under basin irrigation: Fig. 5 shows the iso-time profile of water front advance for the first irrigation event under different water application techniques and tillage practices that was applied at CRI stage of wheat crop for the study year 2012-13. The plots irrigated using MOP and SOP were compared for surface distribution uniformities based on the iso-time profile of water front advance. It was observed that the iso-time profiles were uniform in case of plot irrigated using MOP compared to that of SOP (Fig. 5)

The iso-time profiles under the treatment T-MOP (Fig. 5 ) shows the accumulation of water beyond the length of $35 \mathrm{~m}$ from the head end of field. The reason of accumulation of water may be attributed to the uneven planking operation carried out by farmer after sowing using wooden plank attached to tractor. Planking is generally carried out to crush the hard clods that help in micro leveling, smoothening the soil surface and building a slight compaction necessary after sowing operation. Iso-time profiles were uniform in second year of study (2013-14) as compare to first year of study (2012-13). T-MOP and ZT-MOP treatments showed uniform trend in the iso-time profile of water spread and advance as compare to T-SOP and ZT-SOP treatment respectively, for the first irrigation event that was carried out at CRI stage of crop in the study year 2013-14 (Fig. 6). Moreover, iso-time profiles of the treatment ZT-MOP shows the water distribution pattern was uniform as compare to all other treatments. This may be the combined effect of irrigation using multi-outlet pipes and adapted zero tillage practices.

In case of MOP, main line was extended to the width of basin and multiple minor outlets were punched throughout the length of pipe at the designed distance. Due to multiple minor outlets in MOP, the discharge was divided into number of small entrance stream sizes rather than single full-size stream as under SOP. Thus produces linear inflow of water instead of corner or fan inflow. This helps in uniform distribution of water throughout the basin. Firouzabadi (2012) reported similar observation and recommended gated pipe (Hydroflume) for applying irrigation to achieve uniform distribution of water throughout the field.

In SOP plot, water was applied from the centre of head end of basin with full size stream. Due to one large size stream, water advanced at varying velocity in all

Table 1. Soil physical and chemical properties of experimental plot, Galibkhedi, Karnal.

\begin{tabular}{|c|c|c|c|c|c|c|}
\hline \multirow{2}{*}{$\begin{array}{c}\text { Dept } \\
\text { h } \\
(\mathrm{cm})\end{array}$} & \multirow{2}{*}{$\begin{array}{c}\text { Soil } \\
\text { textural } \\
\text { class }\end{array}$} & \multicolumn{3}{|c|}{$\begin{array}{c}\begin{array}{c}\text { Mineral content } \\
\text { (mass) }\end{array} \\
\end{array}$} & \multirow{2}{*}{$\begin{array}{c}\text { EC } \\
(d S / \\
m)\end{array}$} & \multirow{2}{*}{ pH } \\
\hline & & $\begin{array}{l}\text { Clay } \\
(\%)\end{array}$ & $\begin{array}{l}\text { Silt } \\
(\%)\end{array}$ & $\begin{array}{l}\text { Sand } \\
(\%)\end{array}$ & & \\
\hline $0-15$ & Clay loam & 30.44 & 24.28 & 45.28 & 0.209 & 8.07 \\
\hline $15-30$ & Clay loam & 31.24 & 23.48 & 45.28 & 0.247 & 8.10 \\
\hline $30-45$ & Clay loam & 30.04 & 23.08 & 46.88 & 0.178 & 8.34 \\
\hline $45-60$ & Clay loam & 30.44 & 21.48 & 48.08 & 0.187 & 8.14 \\
\hline $60-75$ & $\begin{array}{l}\text { Silty clay } \\
\text { loam }\end{array}$ & 32.44 & 18.28 & 49.28 & 0.150 & 8.16 \\
\hline $75-100$ & $\begin{array}{l}\text { Silty clay } \\
\text { loam }\end{array}$ & 33.24 & 17.88 & 48.88 & 0.150 & 8.08 \\
\hline
\end{tabular}


Gajanan B. Rajurkar et al. / J. Appl. \& Nat. Sci. 8 (4): 1868-1877 (2016)

Table 2. Application efficiencies for the study years 2012-13 and 2013-14 under wheat crop.

\begin{tabular}{cccccccc}
\hline \multicolumn{7}{c}{$2012-13$} \\
Treatments & $\begin{array}{c}\text { First Irriga- } \\
\text { tion Event }\end{array}$ & $\begin{array}{c}\text { Second Irriga- Third Irriga- } \\
\text { tion Event }\end{array}$ & $\begin{array}{c}\text { Ave. AE (2012- } \\
\text { tion Event }\end{array}$ & $\begin{array}{c}\text { First Irriga- } \\
\text { 13) }\end{array}$ & $\begin{array}{c}\text { Second Irriga- } \\
\text { tion Event } \\
\text { tion Event }\end{array}$ & $\begin{array}{c}\text { Ave. AE } \\
\text { (2013-14) }\end{array}$ \\
\hline$T-M O P$ & 70.83 & 75.93 & 77.78 & 74.85 & 67.39 & 71.90 & 69.65 \\
$T-S O P$ & 66.96 & 70.03 & 72.36 & 69.79 & 64.15 & 68.10 & 66.13 \\
ZT-MOP & 80.08 & 83.32 & 83.84 & 82.41 & 81.46 & 83.70 & 82.58 \\
ZT-SOP & 73.88 & 75.79 & 76.08 & 75.25 & 71.88 & 74.20 & 73.04 \\
$F I R B$ & 75.63 & 76.18 & 78.56 & 76.79 & 75.87 & 78.40 & 77.13 \\
Mean & 73.47 & 76.25 & 77.72 & & 72.15 & 75.26 & \\
STD DEV & 4.94 & 4.71 & 4.17 & & 6.84 & 6.01 & \\
$C V$ & 0.067 & 0.062 & 0.054 & & 0.094 & 0.079 & \\
SE & 2.21 & 2.10 & 1.86 & & 3.059 & 2.690 & \\
\hline
\end{tabular}

Please refer text for T-MOP, T-SOP, ZT-MOP, ZT-SOP and FIRB

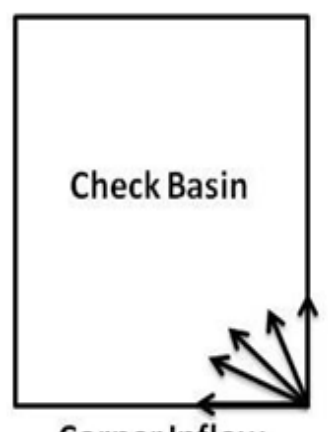

Corner Inflow

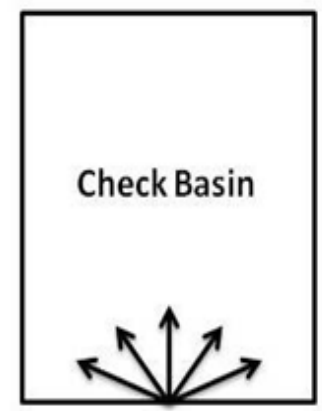

Fan Inflow

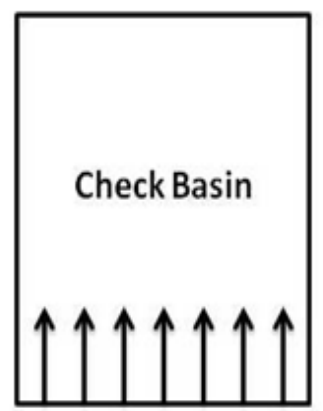

Linear Inflow

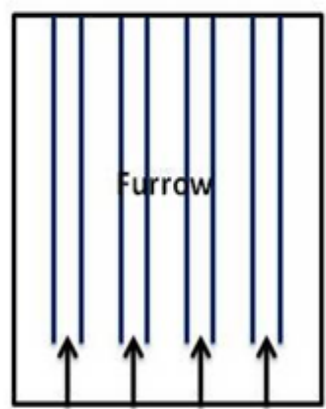

Linear Inflow

Fig.1. Inflow geometry.

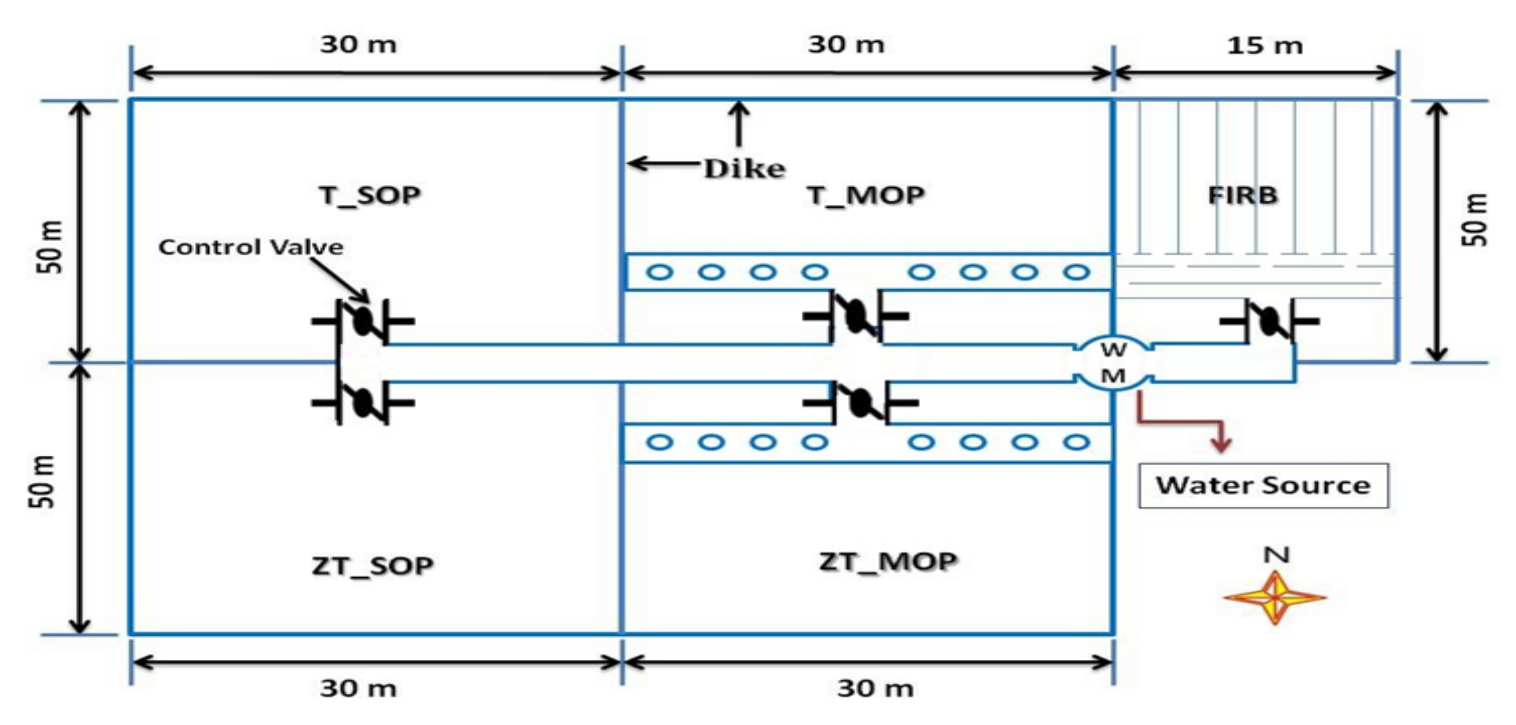

Fig.2. Layout of experimental plots, Galibkhedi, Karnal.

directions but faster in the middle. The time taken by the waterfront to reach about 20 to $25 \mathrm{~m}$ in middle along the length of basin was same as the time required for waterfront to reach the corners of head end of the basin. Owing to such uneven advancement of water within the basin, distribution of water on the surface of basin was not uniform under SOP.

Besides this, Figs. 5 and 6 illustrate that the zero-tilled plot irrigated using SOP and MOP provided better surface distribution uniformity compared to tilled plot. In the zero-tilled plot, the residue of earlier rice crop was left undisturbed in the field. These residues offered resistance to the flow of water and thus waterfront spreading and advance was uniform with time in case of zero-tilled plot. In case of tilled plot, there was no such residue; therefore, resistance was offered only 

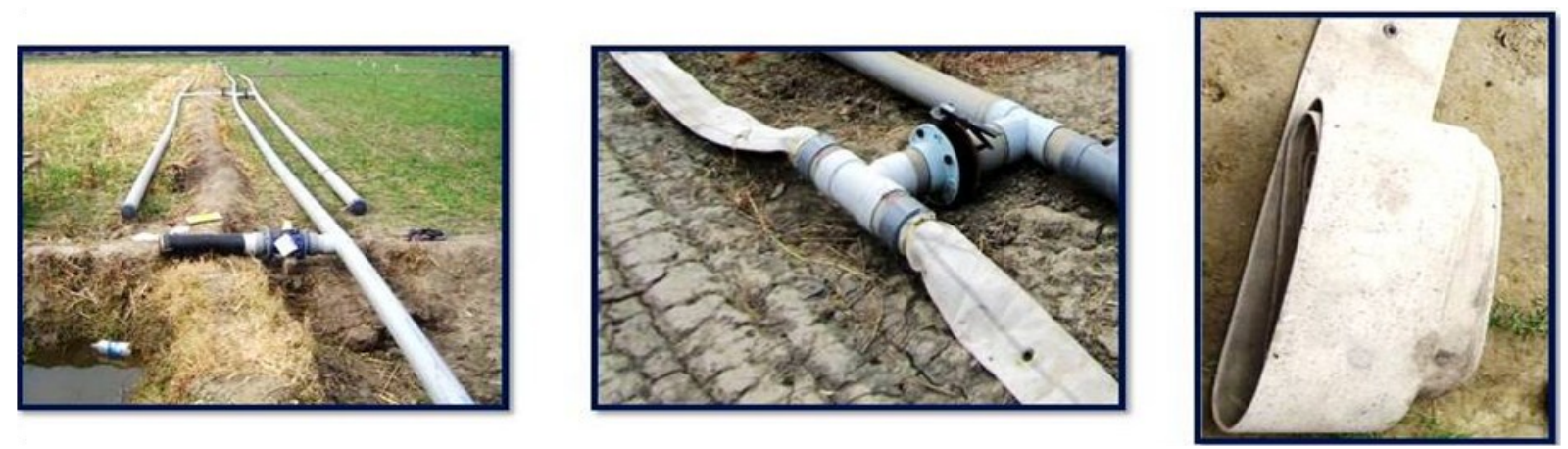

Fig. 3. PVC pipes and collapsible multi-outlets pipe (MOP) .

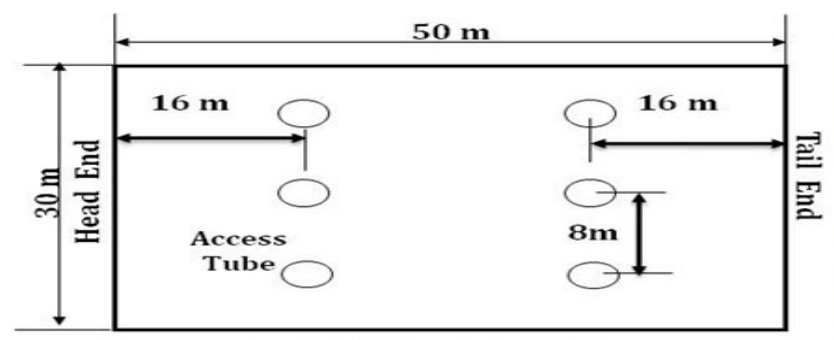

Layout of access tube
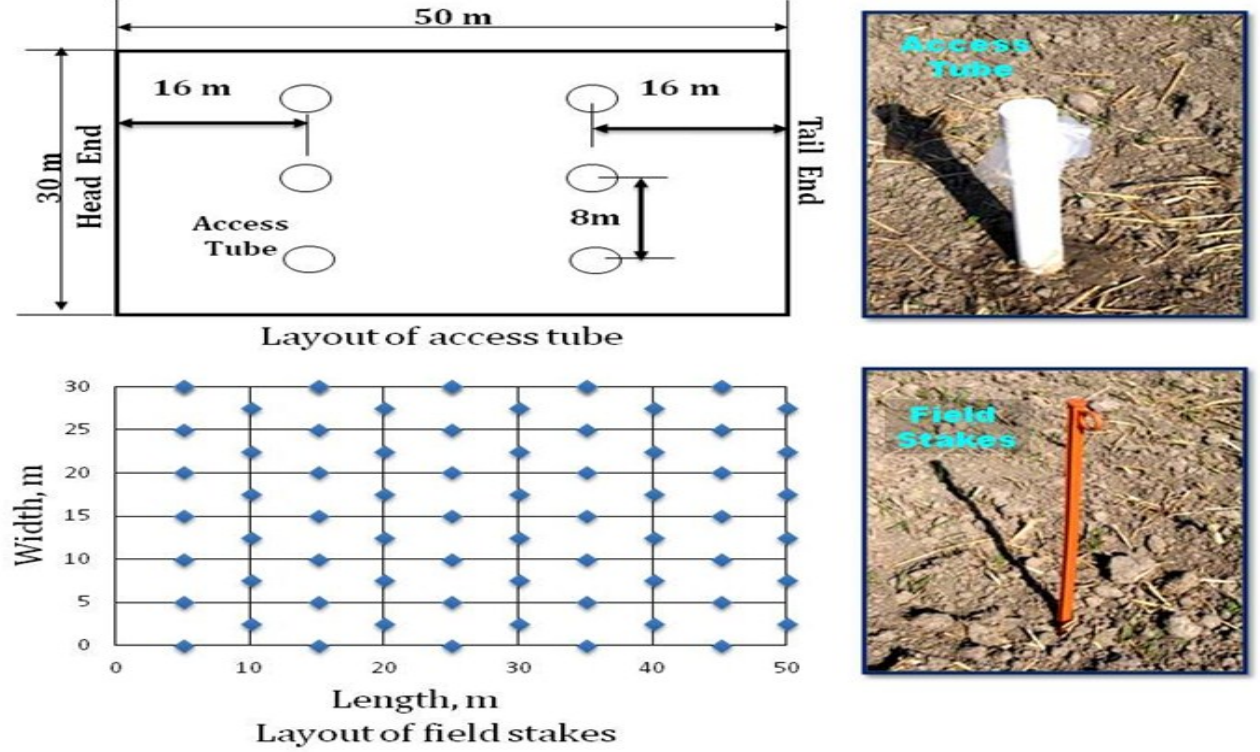

Fig. 4. Layout of access tube and field stakes with installed access tube and field stake in the experimental plots, Galibkhedi, Karnal.

by soil surface to the flow of water. Hence, the better uniformity in water advance front was achieved in zero -tilled plot compared to tilled plot.

The iso-time profiles of water spreading and advance were also compared for the furrow irrigated plot with raised bed planting (FIRB) under both the study year (Fig. 7). It has been found that the advance of waterfront was quick in case of furrow irrigation however, the iso-time profiles shows the uneven distribution of water as compare to the ZT-MOP and T-MOP treatment during both the study years. Surface water distribution was uniform in case of FIRB treatment as compare to T-SOP and ZT-SOP treatment due to linear inflow geometry of water.

Application efficiency: The volume of water stored in the root zone was highest in case of ZT-MOP followed by FIRB and ZT-SOP during both the study years. It is in the order of ZT-MOP $>$ FIRB $>$ ZT-SOP $>$ T-MOP $>$ T-SOP. Application efficiency depends on volume of water stored in root zone from the applied volume to the plot. Thus, the application efficiency improved when volume of actual water stored in root zone increased. Overall, the amount of water stored in root zone was more in case of MOP compared to SOP during both the study years. In addition, the volume of water stored in root zone was high in zero tillage (ZT) plot compared to conventional tillage (T) plot. The increase in soil water storage under zero tillage can be attributed to reduced evaporation (Jones et al., 1968) and improved water retention capacity (Aina, 1979; Opara Nadi and Lal, 1986; Hulugalle et al., 1990). Bhattacharyya et al. (2006) observed similar results of greater water retention under no-tillage compared to conventional tillage. Jemai et al. (2013) also reported that water storage properties in root zone of wheat crop and water availability for plants were enhanced under no tillage practices. Application efficiencies (AE) for irrigation event in the study year 2012-13 and 2013-14 under each treatment is presented in the Fig. 8 .

Fig. 8 illustrates that the application efficiency of T- 

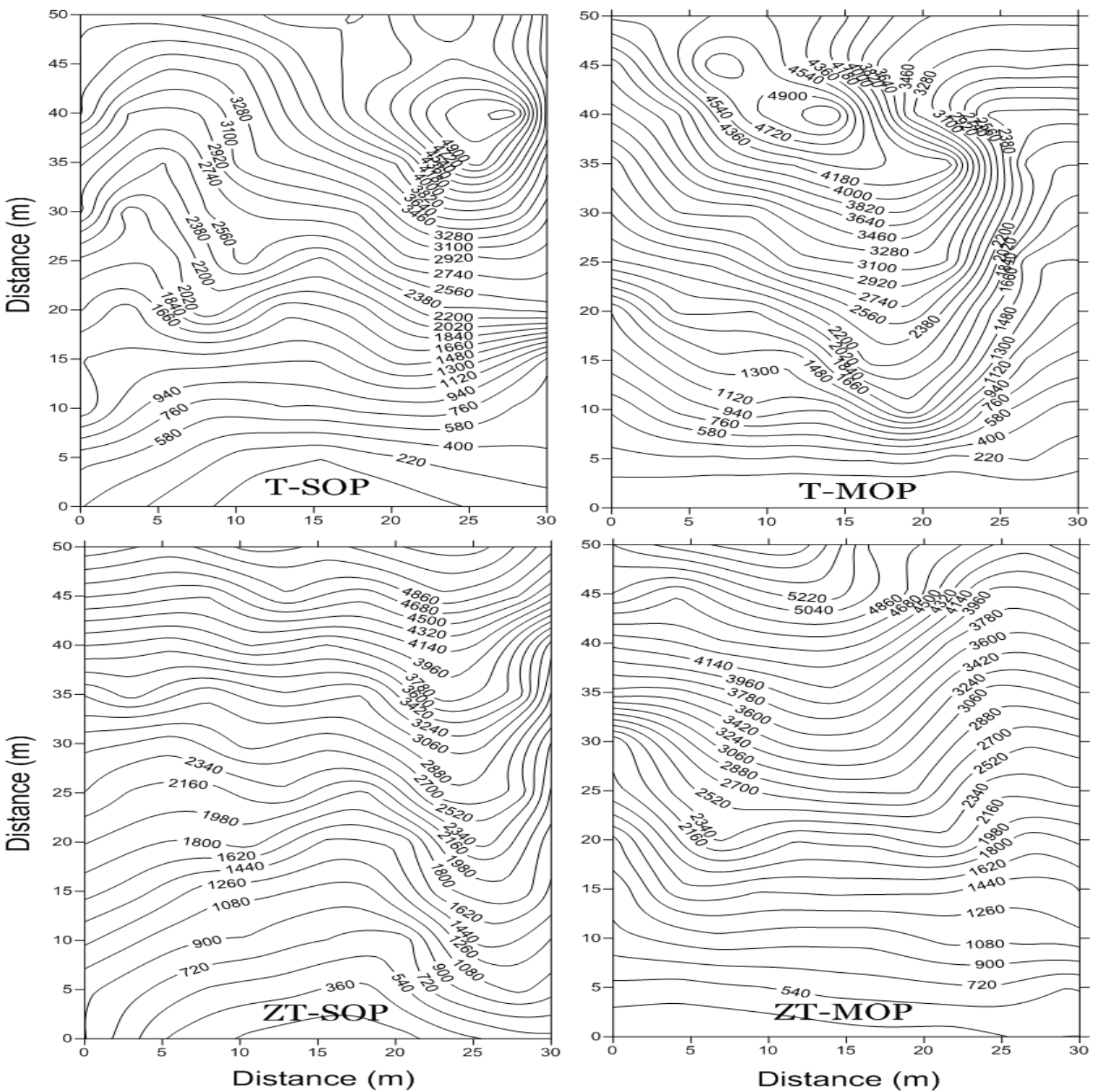

Fig. 5. Iso-time profile of water spreading and advance for the study years 2012-13 under the treatment (a) T-SOP (b) T-MOP (c) ZT-SOP (d) ZT-MOP.

MOP treatment was more than T-SOP treatment under all the irrigation event occurred in 2012-13. Similar result was observed under zero tillage plot (ZTMOP $>$ ZT-SOP). The mean highest application efficiency was obtained in the ZT-MOP $(82.41 \%)$ treatment followed by FIRB $(76.79 \%)$ treatment and the lowest was observed in the controlled T-SOP $(69.79 \%)$ treatment (Table 2). Application efficiency was in the order of ZT-MOP $>$ FIRB $>$ ZT-SOP $>$ T-MOP $>$ TSOP in the study year 2012-13. Further, Mean application efficiency was observed $5.06 \%, 5.46 \%, 7.00 \%$ and $12.63 \%$ more under the treatments T-MOP, ZT-SOP, FIRB and ZT-MOP, respectively, compared to control treatment (T-SOP) in the first year of study.

Similar trend of application efficiency was observed in second study year 2013-14. The mean highest application efficiency was obtained in ZT-MOP treatment $(82.58 \%)$ and lowest was obtained in T-SOP (66.13\%) treatment (Table 2). Mean application efficiencies were observed $3.52 \%, 6.92 \%, 11.01 \%$ and $16.46 \%$ more in the treatments T-MOP, ZT-SOP, FIRB and ZT -MOP, respectively, compared to control treatment (TSOP) in the second study year.

Application efficiencies were observed $5.06 \%$ and $3.52 \%$ more in case of plot irrigated with MOP in tilled plot as compared to SOP plot for 2012-13 and 2013-14, respectively. This might be due to the large discharge stream (as in case of SOP) divides into number of small streams of water flow in case of MOP. This resulted into the line source of application of wa- 

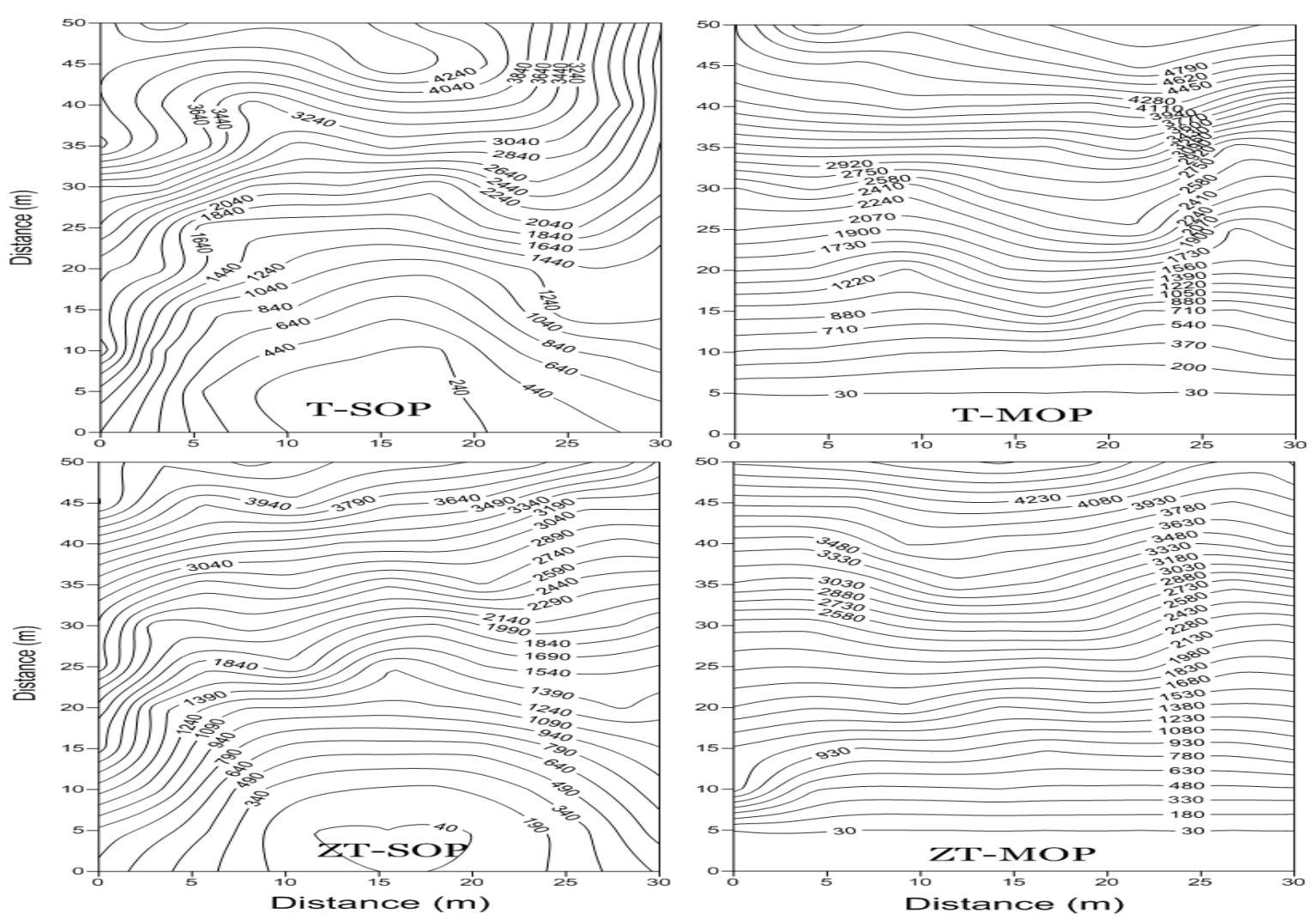

Fig. 6. Iso-time profile of water spreading and advance for the study years 2013-14 under the treatment (a) T-SOP (b) T-MOP (c) ZT-SOP (d) ZT-MOP.

ter along the width of basin that facilitated the linear flow of water throughout the check basin. Earlier researchers also reported the higher application efficiency, distribution efficiency and uniform distribution of water in the soil using Gated pipes, which is similar to multiple outlet pipes used in this study (Omara, 1997; El-Motaleb et al., 2006).

The zero tilled plots with SOP irrigation showed 5.46 $\%$ and $6.92 \%$ more application efficiency than tilled plot with SOP irrigation in the year 2012-13 and 201314 , respectively. Thus only with adapting zero tilled practice could increase application efficiency to the significant level. This could to be attributed to increase in stored water content in case of zero tilled plots.

Statistical analysis showed that the application efficiency of treatment T-MOP is significantly $(\mathrm{P}<0.05)$ higher than the T-SOP treatment and significantly $(\mathrm{P}<0.05)$ lower than the ZT-SOP and FIRB treatment. The application efficiency of the T-SOP treatment was significantly $(\mathrm{P}<0.05)$ lowest among the all treatment. The treatment ZT-MOP achieved significantly highest application efficiency among all other treatments in entire irrigation events. The plot with ZT-SOP treatment showed the significant difference $(\mathrm{P}<0.05)$ in application efficiency when compared with T-SOP and ZT-MOP treatments and however, there was no significant difference in application efficiency when com- pared with T-MOP and FIRB treatment. Application efficiency of the FIRB treatment was significantly $(\mathrm{P}<0.05)$ higher than the T-SOP treatment and significantly lower than the ZT-MOP treatment. Thus among all the treatment applied in the irrigation experiment, ZT-MOP treatment was statistically superior and TSOP was statistically inferior.

\section{Conclusion}

Irrigation experiment to test the collapsible multioutlet pipe (MOP) in farmer's field was carried out in five treatments such as tillage with single outlet pipe (SOP) \& MOP, zero-tillage with SOP \& MOP and FIRB. Results highlighted that MOP has several advantages over conventional SOP irrigation. The application efficiency was more in ZT-MOP, which ensured high water availability for plant growth. Iso-time contours showed that the uniformity in advancement of waterfront was more under ZT-MOP plot that accomplishes uniform distribution of water under ZT-MOP plot. Higher irrigation application efficiency and uniformity of water application under ZT-MOP indicates that the use of multiple outlets pipe irrigation under zero tillage plots is a better option to improve irrigation efficiency and uniformity of water application. Overall, this study concludes that collapsible multi-outlet pipe (MOP) is a suitable option for surface irrigation under zero tillage 
Gajanan B. Rajurkar et al. / J. Appl. \& Nat. Sci. 8 (4): 1868-1877 (2016)
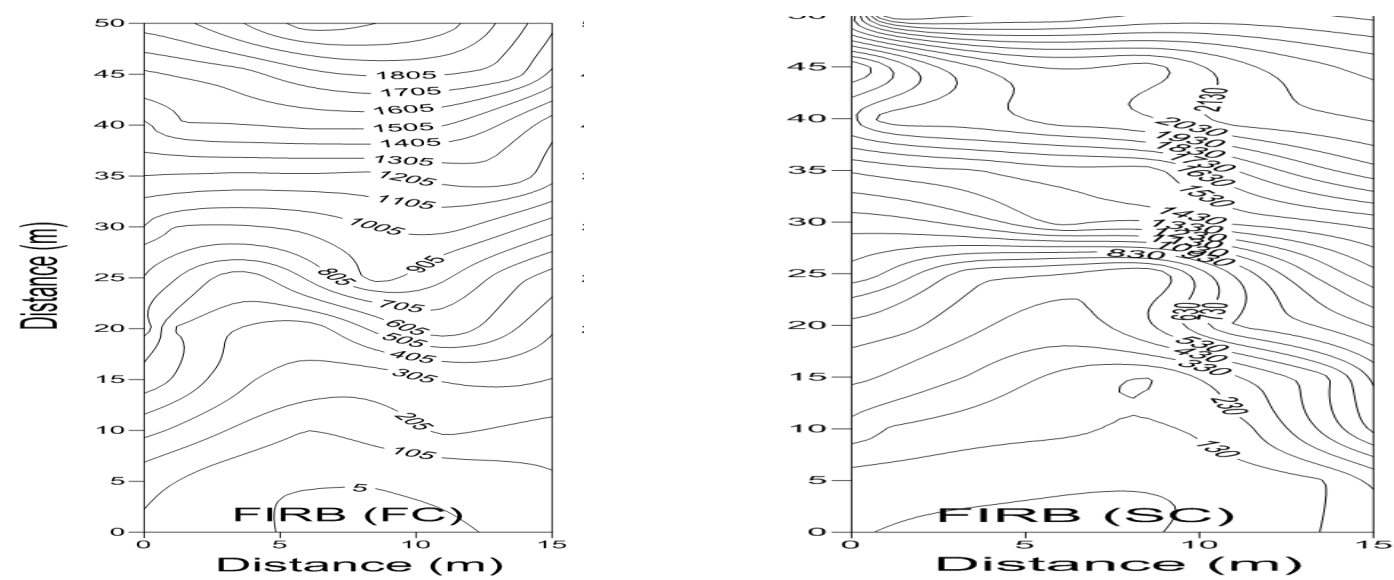

Fig. 7. Iso-time profile of water spreading and advance under the treatment FIRB for the study year 2012-13 (FC=first cycle) and 2013-14 (SC=second cycle).

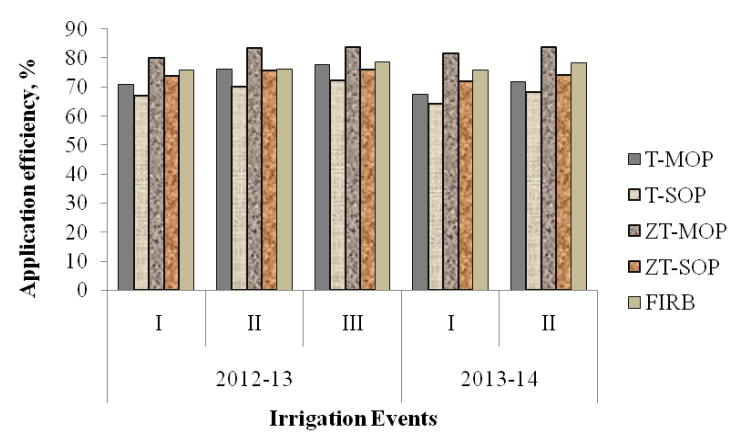

Fig. 8. Effect of different treatments on application efficiency for the study year 2012-13 and 2013-14.

practices, which accomplishes uniform distribution of water with higher application efficiency.

\section{ACKNOWLEDGEMENTS}

Authors would like to thank the CGIAR Research Program on Climate Change, Agriculture and Food Security (CCAFS) and Water, Land and Ecosystems (WLE) for funding this research study. Authors from IWMI, New Delhi would like to thank Dr. Bharat R Sharma, Principal Researcher (Water Resources) and Coordinator, IWMI-India Program and Dr. Pramod Aggarwal, Regional Program Leader (South Asia) for CGIAR Research Program on CCAFS, IWMI, New Delhi office, India for their constant support and encouragement. The author G. B. Rajurkar also likes to thank Indian council of Agricultural Research (ICAR) for providing the (ICAR-SRF) fellowship while conducting doctoral research.

\section{REFERENCES}

Anonymous (2003). ICAR Annual Report. Indian Council of Agricultural Research, New Delhi.

Aina, P.O. (1979). Soil changes resulting from long-term management practices in western Nigeria. Soil Sci. Soc. of America Journal, 43(1): 173-177

Bhattacharyya, R., Prakash, V., Kundu, S. and Gupta, H.S.
(2006). Effect of tillage and crop rotations on pore size distribution and soil hydraulic conductivity in sandy clay loam soil of the Indian Himalayas. Soil and Tillage Research, 86(2):129-140

Bhushan, L., Ladha, J. K., Gupta, R. K., Singh, S., TirolPadre, A., Saharawat, Y. S., Gathala, M. and Pathak, H. (2007). Saving of water and labor in a rice-wheat system with no-tillage and direct seeding technologies. Agronomy Journal, 99(5):1288-1296

Bilskie, J. (1997). Using dielectric properties to measure soil water content. Sensors Magazine, 14:26-32

Bouyoucos, G.J. (1927). The hydrometer as a new method for mechanical analysis of soil. Soil Science, 23, 343353

Burt, C.M., Clemmens, A.J., Strelkoff, T.S., Solomon, K. H., Bliesner, R.D., Hardy, L.A., Howell, T.A. and Eisenhauer, D.E. (1997). Irrigation performance measures: Efficiency and uniformity. Journal of Irrigation and Drainage Engineering, 123 (6):423-442

Clemmens, A.J. and Solomon, K.H. (1997). Estimation of global irrigation distribution uniformity. Journal of Irrigation and Drainage Engineering, 123 (6):454-461

Dechmi, F., Playan, E., Cavero, J., Faci, J.M. and MartinezCob, A. (2003). Wind effects on solid set sprinkler irrigation depth and yield of maize (Zea mays). Irrigation Science, 19:165-173

DeVita, P., Paolo, E.D., Fecondo, G., Di Fonzo, N. and Pisante, M. (2007). No-tillage and conventional tillage effects on durum wheat yield, grain quality and soil moisture content in southern Italy. Soil and Tillage Research, 92(1):69-78

El-Motaleb, I.A.A., El-Saadaw, M.A., Hindy, F.I. and Mattar, M.A. (2006). Development of perforated pipes to improve surface irrigation performance-New Trends in Agricultural Engineering, 1085- 1106. The 14th. Annual Conference of the Misr. Society of Ag. Eng., 22 Nov. 2006

El-Wahed, Mohamed Abd; EL Sabagh, Ayman; Saneoka, Hirofoumi; Abdelkhalek, Abdel Aziz; Barutçular, Celaleddin. (2015). Sprinkler irrigation uniformity and crop water productivity of barley in arid region. Emirates Journal of Food and Agriculture, 27 (10):770-775

Firouzabadi, A.G. (2012). Technical evaluation of low pressure irrigation pipe (Hydroflume) and comparison with 
traditional and sprinkler irrigation systems. Int. J. Agri. Crop Sci., 4 (3):108-113

Fischbach, P.E. and Somerhalder, B.R. (1971). Efficiencies of an automated surface irrigation system with and without runoff re-use system. Trans. of ASAE, 14 (4):717-719

Hassan, S.S.A. (1998). Engineering studies for increasing water distribution uniformity of perforated pipes for surface irrigation system. Ph. D. Th., Agric. Eng. Dept., Cairo Univ. Hastings Co. Gated aluminium irrigation pipe. Hasting Co. Catalouge, Nebraska. USA.

Hlavek, R. (1992). Selection Criteria for irrigation systems. ICID, New Delhi.

Hulugalle, N.R., Lal, R. and Gichuru, M. (1990). Effect of five years of no-tillage and mulch on soil properties and tuber yield of cassava on an acid ultisol in south-eastern Nigeria. Experimental Agriculture, 26(02): 235-240

Jackson, M.L. (1973). Soil chemical analysis. Practice hall, New Delhi.

Jat, M.L., Gathala, M.K., Ladha, J.K., Saharawat, Y.S., Jat, A.S., Kumar, V., Sharma, S.K., Kumar, V. and Gupta, R.K., (2009). Evaluation of precision land leveling and double zero-tillage systems in the rice-wheat rotation: Water use, productivity, profitability and soil physical properties. Soil Tillage Res, 105:112-121

Jat, M.L., Gupta, R., Saharawat, Y.S. and Khosla, R. (2011). Layering precision land leveling and furrow irrigated raised bed planting: Productivity and input use efficiency of irrigated bread wheat in Indo-Gangetic Plains. Am. J. of Plant Sci., (2):578-588

Jemai, I., Aissa, N.B., Guirat, S.B, Ben-Hammouda, M. and Gallali, T. (2013). Impact of three and seven years of no -tillage on the soil water storage, in the plant root zone, under a dry subhumid Tunisian climate. Soil and tillage research, 126:26-33

Jibin, L. and Foroud, N. (2000). Evaluation of a gated pipe basin irrigation method in China.

Jones, J.N., Moody, J.E., Shear, G.M., Moschler, W.W. and Lillard, J.H. (1968). The no-tillage system for corn (Zea mays L.). Agronomy Journal, 60(1):17-20

Karami, V. and Samadi, B.R. (2005). Improved surface irrigation methods by using gated pipes. Technical workshop automated surface irrigation, P: 209-221. (In Farsi)

Li, J. and Rao, M. (2000). Sprinkler water distributions as affected by winter wheat canopy. Irrigation Science, 20 (1):29-35

Li, M., Yan, H., Wang, Y. and Sui, R. (2016). Effect of irrigation amount and uniformity on alfalfa yield and quality under center pivot system. In 2016 ASABE Annual International Meeting (p. 1). American Society of Agricultural and Biological Engineers.

Moteos, L., Montovani, E.C. and Villalobos, F.J. (1997). Cotton response to non-uniformity of conventional sprinkler irrigation. Irrigation Science, 17:47-52

Montazar, A. and Sadeghi, M. (2008). Effects of applied water and sprinkler irrigation uniformity on alfalfa growth and hay yield. Agricultural water management 95, no. 11 (2008): 1279-1287

Omara, A.I. (1997). Implementation and evaluation of gated pipe for furrow irrigation system. M. SC. Th. Agric. Eng. Dept. Alex University.

Opara, N.O.A. and Lal, R. (1986). Effects of tillage methods on physical and hydrological properties of a tropical Alfisol. Zeitschrift fur Pflanzenernahrung und Bodenkunde, 149(2): 235-243

Osman, H.E.B. (2002). Evaluation of surface irrigation using gated pipes techniques in field crops and old horticultural farm. Annals of Agri. Sci. Cairo, 47(2):461-476

Osman, H.E.B. (2000). Gated pipes techniques for improved surface irrigation. Annals of Agric. Sci. Cairo, 1:145-155

Rady, M. Abdel-Hady. (1993). Project evaluation of irrigating system on sandy and calcareous soils, cairo.

Seginer, I. (1983). Irrigation uniformity effect on land and water allocation. Trans. ASAE, 26, 116-122

Sharma, P., Abrol, V. and Sharma, R.K. (2011). Impact of tillage and mulch management on economics, energy requirement and crop performance in maize-wheat rotation in rainfed subhumid inceptisols, India. European journal of agronomy, 34(1):46-51

Stern, J. and Bresler, E. (1983). Nonuniform sprinkler irrigation and crop yield. Irrigation science 4:17-29

Tantawy, M.T.E., Osman, H.E., Hassan, S.S. and El-Khatib, S.I. (2000). Evaluation of surface irrigation under perforated pipe on sugarcane in old valley, Egypt. $8^{\text {th }}$ Conference of Misr Socity, Agr. Eng., 23-33

Varlev, I. (1976). Evaluation of non-uniformity in irrigation and yield. Journal of Irrigation and Drainage, Div., ASCE 102:149-164

Williams, G.S. and Hazen, A. (1920). Hydraulic tables. John willey and sons, New York, New York.

Zimmerman, H. D. (1966). Irrigation. John Wileys Sons, Inc. N.Y. 522 pp.

Zhang, L., Merkley, G.P. and Pinthong, K. (2013). Assessing whole-field sprinkler irrigation application uniformity. Irrig. Sci., 31 (2): 87-105 